\title{
Botulinum Toxin Treatment for Sialorrhea: Evaluation in Patients with Idiopathic Parkinson's Disease
}

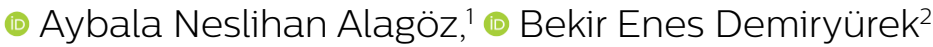

\author{
'Department of Neurology, Kocaeli \\ University Faculty of Medicine, \\ Kocaeli, Turkey \\ Department of Neurology, Bolu \\ Abant İzzet Baysal University Faculty \\ of Medicine, Bolu, Turkey \\ Submitted: 10.06.2019 \\ Accepted: 26.09.2019 \\ Correspondence: \\ Bekir Enes Demiryürek \\ Bolu Abant İzzet Baysal Üniversitesi \\ Tıp Fakültesi, Nöroloji Anabilim Dalı, \\ Bolu, Turkey \\ E-mail: bekirenes10@gmail.com

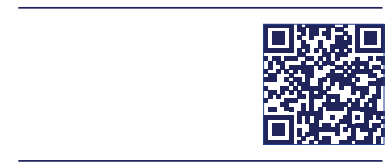 \\ Keywords: Botulinum toxin \\ A; idiopathic Parkinson's \\ disease; sialorrhea. \\ Attribution-NonCommercial 4.0 International License.
}

\begin{abstract}
Objective: The present study aims to evaluate the efficacy and safety of botulinum toxin A (BONT-A) injection therapy on a group of patients with Idiopathic Parkinson's disease (IPD)-associated sialorrhea.

Methods: A retrospective analysis of 21 patients with sialorrhea and IPD treated with BoNT-A at our neurology outpatient clinic was conducted between June 2017- December 2018. BoNT-A was injected into the parotid glands without ultrasound guidance. Pre-treatment sialorrhea severity was quantified according to the Drooling Frequency and Severity Scale (DFSS) and Unified Parkinson's Disease Rating Scale (UPDRS) part 2 item 6 Demographic characteristics of all the patients were recorded. Patients were summoned before the injection, one week after the injection, one month after the injection and three months after the injection and adverse effects on patients associated with the medical treatment were evaluated.
\end{abstract}

Results: A significant decrease in the UPDRS and DSFS scores was observed when the $\left.\right|^{\text {st }}$ week, $I^{\text {st }}$ month and $3^{\text {rd }}$ months after the procedure are evaluated. However, the DSFS and UPDRS scores were significantly lower in the Ist month after the injection with regards to the $3^{\text {rd }}$ month after the injection. No serious side effects were observed in the patients.

Conclusion: In this study, it is demonstrated that BoNT-A injection is simple, safe, tolerable and effective in sialorrhea treatment of patients with IPD. However, further clinical studies involving longer-term follow-up and a larger number of patients are required to confirm and extend our results.

\section{INTRODUCTION}

Idiopathic Parkinson's disease (IPD) is the second most common neurodegenerative disease after Alzheimer's disease. The global prevalence of IPD, which is chronic and progressive, is $1 \%$ of the population over 60 years of age. Non-motor symptoms may also be observed in some patients, along with their motor symptoms (rigidity, bradykinesia, tremor). The frequency of excessive salivation (sialorrhea) in IPD, one of the non-motor symptoms, is between $10 \%-86 \%{ }^{[1-3]}$ Sialorrhea in IPD may lead to social and functional disorders, such as being labelled, social isolation, oral or skin infections, pneumonia, dryness of mouth and dehydration. ${ }^{[1]}$

Pharmacological and non-pharmacological treatments are used in the treatment of sialorrhea. Among the non-pharmacological treatments, the effectiveness of treatments, such as behavioural therapy or gum chewing, is limited. ${ }^{[4]}$ Even though surgical treatments and radiotherapy on the salivary glands are effective treatments in the reduction of salivation due to the side effects, such as loss of taste and permanent xerostomia, it can only be used on a limited number of patients. ${ }^{[5]}$

The use of anticholinergic agents in pharmacological treatment that reduce salivation is limited due to their common side effects. The side effects of local anticholinergic agents (atropine, glycopyrrolate and ipratropium bromide) are lower; however, their effect in sialorrhea treatment is limited. ${ }^{[6]}$

Another pharmacological agent is botulinum toxin (BONT) produced by the Clostridium botulinum bacterium. BONT, which has two serotypes of type $A$ and type $B$, affects SNARE and SNAP proteins to inhibit the release of acetylcholine from the presynaptic terminal at the neuromuscular junction. BONT was first used in the 1980s to treat focal and generalized dystonia, such as blepharospasm, craniocervical dystonia. In the American Academy of Neurology (AAN) 2016 guidelines, the efficacy of BONT treat- 
ment in craniocervical dystonia, extremity spasticity and chronic migraine is reported as evidence level $A$ and in blepharospasm as evidence level $\mathrm{B}^{\left[{ }^{[7]}\right.}$ Moreover, BONT is used for the treatment of tremor, camptocormia, overactive bladder and sialorrhea complaints in IPD. Local BONT administration on major salivary glands is reported to be effective in the treatment of sialorrhea by the Movement Disorder Society (MDS). ${ }^{[4,8,9]}$

The present study aims to evaluate the efficacy and safety of BONT-A injection therapy on a group of patients with IPD-associated sialorrhea and to determine whether it has other benefits.

\section{MATERIALS AND METHODS}

In this study, 21 patients over 18 years of age, who were diagnosed with IPD based on the Unified Parkinson's Disease Rating Scale (UPDRS) and administered medical treatment for Parkinson's Disease by the same clinician at neurology outpatient clinic between June 2017-December 2018, were included. Twenty-one patients with sialorrhea complaints who were administered BONT were evaluated retrospectively. Patients who were not treated with BONT and received no treatment for sialorrhea before admitting to our clinic were included in this study.

All possible adverse effects and risks related to the applications were explained to the patients or their legal guardians, and written informed consent was received before treatment with OnabotulinumtoxinA.

One hundred units of OnabotulinumtoxinA (BoNT-A; Botox ${ }^{\circledR}$, Allergan, USA) were reconstituted with $2 \mathrm{~mL}$ of $0.9 \% \mathrm{NaCl}$ solution ( 5 units per $0.1 \mathrm{~mL}$ ), and the toxin was used within $4 \mathrm{~h}$ after its reconstitution. BoNT-A injection of $40 \mathrm{IU}$ was administered bilaterally at two different points of each parotid gland with a 30 -gauge insulin syringe by the same clinician, using palpation method considering the facial neuroanatomy. Toxin was administered in the same total dose to all patients to evaluate the efficacy of the medication.

To determine the degree of the hypersalivation problem, UPDRS part 2 item 6 (from 0 to 4, 0=Normal, 4=Marked drooling requires constant tissue or handkerchief) and Drooling Severity and Frequency Scale (DSFS) were applied to the patients. Patients with UPDRS part 2 item 6 score $\geq 2$, DSFS severity score $\geq 4$ and/or DFS frequency score $\geq 3$ were included. DSFS is shown in Table I. ${ }^{10]}$

The demographic characteristics of all patients were recorded. Patients were summoned before the injection, one week after the injection, one month after the injection and three months after the injection and UPDRS part 2 item 6 and DSFS and hypersalivation levels were evaluated by the same clinician. Adverse effects on patients associated with the medical treatment were evaluated.

The present study was approved by the Local Ethics Committee.
Table I. Drooling Severity and Frequency Scale (DSFS)

\begin{tabular}{lc}
\hline Drooling & Points \\
\hline Severity & \\
Dry-never drools & I \\
Mild-only lips wet & 2 \\
$\quad$ Moderate-drool reaches the lips and chin & 3 \\
$\quad$ Severe-drool drips off chin and onto clothing & 4 \\
Profuse-drooling off the body and onto & \\
objects (furniture, books) & 5 \\
Frequency & \\
$\quad$ Never drools & 1 \\
$\quad$ Occasionally drools & 2 \\
$\quad$ Frequently drools & 3 \\
Constantly drools & 4 \\
\hline
\end{tabular}

The score of DSFS equals the sum of the severity and frequency sub-scores.

\section{RESULTS}

The age distribution of the patients participating in this study varies between 45 to 90 , whereas the average age was $67,10 \pm 10.56$ years. $54.2 \%(n=I I)$ of the cases are male and $47.6 \%(n=10)$ were female. Parkinson's duration varied between 2 to 9 years and the average was $5.7 \mathrm{I} \pm \mathrm{I} .95$ years.

No statistically significant relevance was detected between the total UPDRS and DSFS total scores and Parkinson's durations before the procedure $(p=0.418, p=0.825$, respectively).

UPDRS measurements indicate a significant difference in the follow-ups $(p<0.01)$ when the follow-up with the significant difference was analysed; the difference in UPDRS measurements of the $I^{\text {st }}$ week after the procedure, $I^{\text {st }}$ month after the procedure and $3^{\text {rd }}$ month after the procedure with regards to pre-procedure were statistically significant (all $p=0.001 ; p<0.05$ ). The increase in the $3^{\text {rd }}$ month after the procedure with regards to the $I^{\text {st }}$ week after the procedure was also statistically significant ( $\left.\right|^{\text {st }}$ week $-3^{\text {rd }}$ month $\left.p=0.004 ; p<0.05\right)$. Differences between other follow-ups were not statistically significant $\left(\left.\right|^{\text {st }}\right.$ week- ${ }^{\text {st }}$ month: I.000; I $^{\text {st }}$ month-3 ${ }^{\text {rd }}$ month: I.000; p>0.05). Table 2 shows the evaluation of UPDRS measurements according to the follow-ups.

DSFS severity measurements indicated significant difference with regards to the follow-ups $(p<0.01)$; when the follow-up with the significant difference was analysed, the difference in DSFS severity after the procedure, in the ${ }^{\text {st }}$ week after the procedure, in the $\left.\right|^{\text {st }}$ month after procedure and in the $3^{\text {rd }}$ month after the procedure with regards to the pre-procedure measurements were statistically significant ( $p=0.001 ; p=0.001 ; p=0.009 ; p<0.01$, respectively). The increase measured in the $3^{\text {rd }}$ month with regards to the $I^{\text {st }}$ week after the procedure was also statistically significant $(p=0.025 ; p<0.05)$. Differences between other follow-ups were not statistically significant $\left(I^{\text {st }}\right.$ week- $\left.\right|^{\text {st }}$ month: I.000; $1^{\text {st }}$ month-3 $3^{\text {rd }}$ month: 0.162; $\left.\mathrm{p}>0.05\right)$. 
DSFS frequencies differed significantly in the follow-ups $(p<0.01)$; when the follow-up with the significant difference is analysed, the difference in DSFS frequency in the $I^{\text {st }}$ week after the procedure, in the $I^{\text {st }}$ month after the procedure and in the $3^{\text {rd }}$ month after the procedure with regards to the pre-procedure were statistically significant $(p=0.00$ I; $p=0.00$ I; $p=0.05 ; p<0.05$, respectively $)$. Differences between other follow-ups were not statistically significant $\left(\left.\right|^{\text {st }}\right.$ week- $\left.\right|^{\text {st }}$ month: I.000; $\left.\right|^{\text {st }}$ week- $3^{\text {rd }}$ month: $0.101 ; 1^{\text {st }}$ month-3 ${ }^{\text {rd }}$ month: 1.000; $\mathrm{p}>0.05$ ).

Total DSFS measurements differed significantly in the follow-ups $(p<0.01)$; when the follow-up with the significant difference is analysed, the difference in total DSFS measurement in the $1^{\text {st }}$ week after the procedure, in the $1^{\text {st }}$ month after the procedure and in the $3^{\text {rd }}$ month after the procedure with regards to the pre-procedure were statistically significant $(p=0.00 I ; p=0.00 I ; p=0.017 ; p<0.05$ respectively). The increase in the $3^{\text {rd }}$ month with regards to the $I^{\text {st }}$ week after the procedure was also statistically significant $(p=0.003 ; p<0.01)$. Differences between other follow-ups were not statistically significant $\left(I^{\text {st }}\right.$ week- $\left.\right|^{\text {st }}$ month: 1.000; $1^{\text {st }}$ month-3 $3^{\text {rd }}$ month: 0.189; $p>0.05$ ). Table 3 shows the evaluation of the DSFS measurements according to the follow-ups.
NCSS (Number Cruncher Statistical System) 2007 (Kaysville, Utah, USA) program was used for the statistical analyses. Descriptive statistical methods (mean, standard deviation, median, frequency, percentage, minimum, maximum) were used in the evaluation of the study data. The conformity of the quantitative data to normal distribution was tested using the Shapiro-Wilk test and graphical browsers. Friedman test and post hoc Dunn Bonferroni test were used for the analysis with regards to follow-ups. For relevance with regards to Parkinson's duration, Spearman correlation analysis was used. Statistical significance was assumed to be $p<0.05$.

\section{DISCUSSION}

In this study, as the result of BONT-A administration to the parotid glands for sialorrhea treatment in idiopathic Parkinson's patients, a significant decrease in the UPDRS and DSFS scores is observed when the $1^{\text {st }}$ week, $\left.\right|^{\text {st }}$ month and $3^{\text {rd }}$ months after the procedure are evaluated. However, the DSFS and UPDRS scores are significantly lower in the $I^{\text {st }}$ month after the injection with regards to the $3^{\text {rd }}$ month after the injection. There is no significant difference between the $I^{\text {st }}$ week and the $I^{\text {st }}$ month after

Table 2. Analysis of UPDRS measurement with regards to follow-ups

\begin{tabular}{|c|c|c|c|c|c|c|}
\hline & Pre-procedure & $\begin{array}{c}\text { | }{ }^{\text {st }} \text { week } \\
\text { after procedure }\end{array}$ & $\begin{array}{l}\text { Ist month } \\
\text { after procedure }\end{array}$ & $\begin{array}{l}3^{\text {rd }} \text { month } \\
\text { after procedure }\end{array}$ & ${ }^{a} \mathbf{p}$ & $\begin{array}{c}\text { bPost Hoc } \\
\text { test }\end{array}$ \\
\hline \multirow[t]{2}{*}{ UPDRS } & & & & & $0.001^{* *}$ & $1>2,3,4$ \\
\hline & & & & & & $2>4$ \\
\hline Avg $\pm S D$ & $3.43 \pm 0.51$ & $0.95 \pm 0.86$ & I. $14 \pm 0.79$ & $1.38 \pm 0.92$ & & \\
\hline Median & 3.00 & 1.00 & 1.00 & 1.00 & & \\
\hline Min-Max & $3-4$ & $0-3$ & $0-3$ & $0-4$ & & \\
\hline
\end{tabular}

${ }^{\mathrm{a} F r i e d m a n}$ Test; ${ }^{\circ}$ Dunn Bonferroni Test; ${ }^{* *} \mathrm{p}<0.0$ I. UPDRS: Unified Parkinson's Disease Rating Scale.

Table 3. Analysis of DSFS measurements with regards to follow-ups

\begin{tabular}{|c|c|c|c|c|c|c|}
\hline & Pre-procedure & $\begin{array}{c}\text { Ist week } \\
\text { after procedure }\end{array}$ & $\begin{array}{l}\text { Ist month } \\
\text { after procedure }\end{array}$ & $\begin{array}{l}3^{\text {rd }} \text { month } \\
\text { after procedure }\end{array}$ & ${ }^{\mathrm{a}} \mathbf{p}$ & $\begin{array}{c}\text { bPost Hoc } \\
\text { test }\end{array}$ \\
\hline \multirow[t]{2}{*}{ DSFS severity } & & & & & $0.00 I^{* *}$ & $1>2,3,4$ \\
\hline & & & & & & $2>4$ \\
\hline $\operatorname{Avg} \pm S D$ & $4.24 \pm 0.63$ & $1.95 \pm 0.86$ & $2.14 \pm 0.73$ & $2.76 \pm 0.99$ & & \\
\hline Median & 4 & 2 & 2 & 2 & & \\
\hline Min-Max & $3-5$ & $1-4$ & $1-4$ & $1-5$ & & \\
\hline DSFS frequency & & & & & $0.00 I^{* *}$ & $1>2,3,4$ \\
\hline Avg $\pm S D$ & $3.29 \pm 0.72$ & $1.86 \pm 0.79$ & $2.14 \pm 0.73$ & $2.48 \pm 0.93$ & & \\
\hline Median & 3 & 2 & 2 & 2 & & \\
\hline Min-Max & $2-4$ & $1-3$ & $1-4$ & $1-4$ & & \\
\hline \multirow[t]{2}{*}{ DSFS Total } & & & & & $0.001^{* *}$ & $1>2,3,4$ \\
\hline & & & & & & $2>4$ \\
\hline Avg $\pm S D$ & $7.52 \pm 1.25$ & $3.8 I \pm 1.08$ & $4.24 \pm 0.99$ & $5.24 \pm 1.42$ & & \\
\hline Median & 7.0 & 4.0 & 4.0 & 5.0 & & \\
\hline Min-Max & $5-9$ & $2-6$ & $2-6$ & $3-8$ & & \\
\hline
\end{tabular}

${ }^{a}$ Friedman Test; 'Dunn Bonferroni Test; " $\mathrm{p}<0.01$. DSFS: Drooling Severity and Frequency Scale. 
the injection. No serious side effects are observed in the patients.

There are various opinions on the pathophysiology of sialorrhea in IPD. First, it was presumed that the increase in salivary flow in Parkinson's patients might be due to oral irritation. However, in many studies, it is reported that salivation decreases in Parkinson's patients, compared to healthy individuals. Another opinion is that the salivary release is extremely increased in association with the medication used in treatment, such as clozapine and cholinesterase inhibitor, to cause sialorrhea. The most common opinion regarding pathophysiology is swallowing disorder associated with oropharyngeal dysphagia that arises from bradykinesia and sialorrhea caused in association with this. ${ }^{[1]}$

BONT-A was first administered in sialorrhea treatment by Bushar in 1997. Toxin affects salivary glands by blocking the release of presynaptic acetylcholine in the parasympathetic ganglia. Its effect is temporary, depending on the regeneration of the presynaptic terminal and lasts around three months on average. ${ }^{[12]}$

There is no clear consensus on which salivary glands to administer BONT in the treatment of sialorrhea. However, in the literature, there are studies where BONT injection is administered on various salivary glands, such as on the parotid glands, submandibular glands, ${ }^{[13-15]}$ both parotid and submaxillary glands ${ }^{[6]}$ and both parotid and submandibular glands. ${ }^{[17]}$ However, in most of the previous studies, BONT injection is administered on the parotid gland. ${ }^{[18]}$

In our study, BONT injection was administered on the bilateral parotid glands, and a significant decrease in sialorrhea was observed.

The standard effective doses and duration of BONT toxin administered in IPD-associated sialorrhea treatment are not definite. However, it is reported in the studies that I0-100 IU BONTA and an average of 2500 IU BONTB injections have similar effects. ${ }^{[12]}$

In the study conducted by Breheret et al.,, ${ }^{[1]}$ BONT-A treatment was administered on submandibular and parotid glands with ultrasound guidance in seven different alternative doses and it was reported that the most effective doses were $20 \mathrm{IU}$ on submandibular glands and I5 IU on parotid glands.

In a double-blind, randomised placebo study conducted by Lagalla et al., ${ }^{[19]} 50$ IU BONT-A was administered on the bilateral parotid glands of 32 Parkinson's patients and compared with placebo. At the end of the $\mathrm{I}^{\text {st }}$ month, it was observed that the UPDRS salivation score decreased by $37 \%$ in the BONT group and by $6 \%$ in the placebo group.

In another study conducted in Italy, BONT-A was administered to the submandibular and parotid glands of 20 Parkinsonism patients and a significant decrease in their DSFS scores was observed in the $I^{\text {st }}$ week and it was reported to last for an average of one month. ${ }^{[14]}$
In another double-blind, multicentre study conducted on a total of 54 Parkinson's patients, between 1500 to $3500 \mathrm{IU}$ BONT-B was administered to patients, and it was reported that in all three groups, there was a significant decrease in DSFS scores and saliva flow rates. ${ }^{[20]}$ However, in another study conducted on PD patients by Narayanaswami et al., ${ }^{[2]]}$ it was reported that BONTA administration of 30 IU to submandibular glands and $20 \mathrm{IU}$ to parotid glands did not provide any significant improvement in sialorrhea treatment. In addition, in a study, a total BONT-A dose over $50 \mathrm{IU}$ was reported to be more effective than doses of $50 \mathrm{IU}$ and lower. ${ }^{[2]}$

In our study, a total BONTA dose of $80 \mathrm{IU}$ was administered. A significant improvement was observed in the patients' saliva flow. It is determined that BONT-A efficacy lasted for an average of three months. The significant improvement in sialorrhea after BONT treatment in most of the studies conducted, despite the wide range of dosages and effectiveness intervals, makes us believe that BONTA efficacy may be dependent on etiologic factor, disease duration and body mass index of the patients and the other medications they use.

As the response to BONT-A treatment is temporary, repeated injections are required. However, there are only a limited number of studies evaluating the effects of the repeated BONT treatment on sialorrhea.

In a study conducted by Breheret et al., ${ }^{[16]}$ repeated injections were administered on some patients with sialorrhea associated with ALS, PD, cerebral palsy and other neurological diseases and it was reported that after repeated BONT-A injection in 5 of 14 patients with idiopathic Parkinson's disease, $66 \%$ of the patients benefited the treatment.

In a study conducted on 16 idiopathic Parkinson's patients with sialorrhea from Turkey, repeated BoNT-A injection was administered to bilateral parotid glands and a significant difference was observed both in the reduction of sialorrhea before and after the procedure and in the efficacy between the first and the repeated injection. ${ }^{[18]}$

In our study, BoNT-A injection was administered in a single dose and the efficacy of the repeated injections was not evaluated.

As similar to other studies, in our study, no side effects associated with BONT-A treatment were observed. However, dryness of mouth being the most frequent, adverse effects, such as swallowing and chewing difficulties, repeating mandibular joint subluxation, were reported. It is presumed that these adverse effects are due to the invasion of BONT-A in the tissues adjacent to the salivary glands. ${ }^{[18]}$

The limitations of our study are, firstly, single BONT administration instead of repeated injections and the incapability to evaluate long term effects. Secondly, the injections were administered by the palpation method considering the facial neuroanatomy instead of ultrasound guidance. However, it can be seen that half of the studies in the literature were conducted with ultrasound guidance and the 
other half with EMG or palpation methods. ${ }^{[16]}$ Also, another study comparing these two methods indicated that it is not absolutely necessary to perform the injections with ultrasound guidance. ${ }^{[23]}$

We administered the BONT-A injection with the palpation method, as the parotid glands are superficial and easily accessible.

\section{CONCLUSION}

In this study, it is demonstrated that BoNT-A injection is simple, safe, tolerable and effective in sialorrhea treatment of the patients with IPD. However, further clinical studies involving longer-term follow-up and a larger number of patients are required to confirm and extend our results.

Data Availability

All the raw data used to support the findings of this study are available from the corresponding author upon request.

Acknowledgements

We thank all authors for contributions to prepare this study.

Financial Disclosure

The authors declared that this study has received no financial support. All of the financial expenses were greeted by the authors of this paper.

Ethics Committee Approval

Approved by the local ethics committee (date: 11.01 .2019 , no: 74563$)$.

Informed Consent

Retrospective study.

Peer-review

Internally peer-reviewed.

Authorship Contributions

Concept: B.E.D.; Design: B.E.D.; Supervision: A.N.A.; Fundings: B.E.D., A.N.A.; Materials: B.E.D.; Data: A.N.A.; Analysis: A.N.A.; Literature search: B.E.D.; Writing: B.E.D.; Critical revision: A.N.A.

Conflict of Interest

None declared.

\section{REFERENCES}

1. Kalf JG, de Swart BJ, Borm GF, Bloem BR, Munneke M. Prevalence and definition of drooling in Parkinson's disease: a systematic review. J Neurol 2009;256:1391-6. [CrossRef]

2. Bruno VA, Fox SH, Mancini D, Miyasaki JM. Botulinum Toxin Use in Refractory Pain and Other Symptoms in Parkinsonism. Can J Neurol Sci 2016;43:697-702. [CrossRef]

3. Cardoso F. Botulinum toxin in parkinsonism: The when, how, and which for botulinum toxin injections. Toxicon 2018;147:107-10.

4. Tumilasci OR, Cersósimo MG, Belforte JE, Micheli FE, Benarroch EE, Pazo JH. Quantitative study of salivary secretion in Parkinson's disease. Mov Disord 2006;21:660-7. [CrossRef]
5. Hawkey NM, Zaorsky NG, Galloway TJ. The role of radiation therapy in the management of sialorrhea: A systematic review. Laryngoscope 2016;126:80-5. [CrossRef]

6. Gómez-Caravaca MT, Cáceres-Redondo MT, Huertas-Fernández I, Vargas-González L, Carrillo F, Carballo M, et al. The use of botulinum toxin in the treatment of sialorrhea in parkinsonian disorders. Neurol Sci 2015;36:275-9. [CrossRef]

7. Jankovic J. Botulinum toxin: State of the art. Mov Disord 2017;32:1131-8. [CrossRef]

8. Nicaretta DH, de Rosso AL, Maliska C, Costa MM. Scintigraphic analysis of the parotid glands in patients with sialorrhea and Parkinson's disease. Parkinsonism Relat Disord 2008;14:338-41. [CrossRef]

9. Kalf JG, Munneke M, van den Engel-Hoek L, de Swart BJ, Borm GF, Bloem BR, et al. Pathophysiology of diurnal drooling in Parkinson's disease. Mov Disord 2011;26:1670-6. [CrossRef]

10. Thomas-Stonell N, Greenberg J. Three treatment approaches and clinical factors in the reduction of drooling. Dysphagia 1988;3:73-8.

11. Srivanitchapoom P, Pandey S, Hallett M. Drooling in Parkinson's disease: a review. Parkinsonism Relat Disord 2014;20:1109-18. [CrossRef]

12. Ruiz-Roca JA, Pons-Fuster E, Lopez-Jornet P. Effectiveness of the Botulinum Toxin for Treating Sialorrhea in Patients with Parkinson's Disease: A Systematic Review. J Clin Med 2019;8:317. [CrossRef]

13. Jongerius PH, Rotteveel JJ, van den Hoogen F, Joosten F, van Hulst K, Gabreëls FJ. Botulinum toxin A: a new option for treatment of drooling in children with cerebral palsy. Presentation of a case series. Eur J Pediatr 2001;160:509-12. [CrossRef]

14. Mancini F, Zangaglia R, Cristina S, Sommaruga MG, Martignoni E, Nappi G, et al. Double-blind, placebo-controlled study to evaluate the efficacy and safety of botulinum toxin type $\mathrm{A}$ in the treatment of drooling in parkinsonism. Mov Disord 2003;18:685-8. [CrossRef]

15. Scheffer AR, Erasmus C, van Hulst K, van Limbeek J, Jongerius $\mathrm{PH}$, van den Hoogen FJ. Efficacy and duration of botulinum toxin treatment for drooling in 131 children. Arch Otolaryngol Head Neck Surg 2010;136:873-7. [CrossRef]

16. Breheret R, Bizon A, Jeufroy C, Laccourreye L. Ultrasound-guided botulinum toxin injections for treatment of drooling. Eur Ann Otorhinolaryngol Head Neck Dis 2011;128:224-9. [CrossRef]

17. Møller E, Karlsborg M, Bardow A, Lykkeaa J, Nissen FH, Bakke M. Treatment of severe drooling with botulinum toxin in amyotrophic lateral sclerosis and Parkinson's disease: efficacy and possible mechanisms. Acta Odontol Scand 2011;69:151-7. [CrossRef]

18. Şen A, Arpaci B. Effects of Repeated Botulinum Toxin Treatment for Sialorrhea in Patients with Parkinson's Disease. Noro Psikiyatr Ars 2015;52:69-72. [CrossRef]

19. Lagalla G, Millevolte M, Capecci M, Provinciali L, Ceravolo MG. Botulinum toxin type A for drooling in Parkinson's disease: a double-blind, randomized, placebo-controlled study. Mov Disord 2006;21:704-7. [CrossRef]

20. Chinnapongse R, Gullo K, Nemeth P, Zhang Y, Griggs L. Safety and efficacy of botulinum toxin type B for treatment of sialorrhea in Parkinson's disease: a prospective double-blind trial. Mov Disord 2012;27:219-26. [CrossRef]

21. Narayanaswami P, Geisbush T, Tarulli A, Raynor E, Gautam S, Tarsy $\mathrm{D}$, et al. Drooling in Parkinson's disease: A randomized controlled trial of incobotulinum toxin A and meta-analysis of Botulinum toxins. Parkinsonism Relat Disord 2016;30:73-7. [CrossRef]

22. Vashishta R, Nguyen SA, White DR, Gillespie MB. Botulinum toxin for the treatment of sialorrhea: a meta-analysis. Otolaryngol Head Neck Surg 2013;148:191-6. [CrossRef]

23. Svetel M, Vasić M, Dragasević N, Pekmezović T, Petrović I, Kostić $\mathrm{V}$. Botulinum toxin in the treatment of sialorrhea. Vojnosanit Pregl 2009;66:9-12. [CrossRef] 


\section{Siyalore Tedavisinde Botulinum Toksin Tedavisi: İdiyopatik Parkinson Hastalarının Değerlendirilmesi}

Amaç: Bu çalışmada, idiyopatik Parkinson hastalığına (iPH) bağlı siyaloresi olan bir grup hasatada botulinum toksin A (BONT-A) enjeksiyon tedavisinin etkinliği ve güvenilirliğinin değerlendirilmesi aynı zamanda daha başka yararlarının olup olmadığıın belirlenmesi amaçlandı.

Gereç ve Yöntem: Nöroloji polikliniğimizde BoNT-A ile tedavi edilen siyalore ve IPH'lı 2 I hastanın geriye dönük analizi Haziran 20 I7-Aralık $20 । 8$ tarihleri arasında yapıldı. BoNT-A, ultrason rehberliği olmadan parotis bezlerine enjekte edildi. Tedavi öncesi siyalore şiddeti, Düşme Sıklığı ve Ciddiyet Ölçeği (DFSS) ve Unified Parkinson Hastalık Değerlendirme Ölçeği (UPDRS) bölüm 2 madde 6'ya göre ölçüldü. Tüm hastaların demografik özellikleri kaydedildi. Hastalar enjeksiyondan önce, enjeksiyondan bir hafta sonra, enjeksiyondan bir ay sonra ve enjeksiyondan üç ay sonra çağrıldı ve hastalar üzerindeki tıbbi etkiler ile ilişkili olumsuz etkiler değerlendirildi.

Bulgular: Bu çalşsmada IPH olan hastalarda siyalore tedavisinde parotis bezlerine BONT-A uygulaması sonucunda işlem öncesi UPDRS ve DSFS skorları ile işlem sonrası birinci hafta birinci ay ve üçüncü ay değerlendirildiğinde anlamlı derecede azalma saptandı. Bununla birlikte DSFS ve UPDRS skorları enjeksiyon sonrası birinci haftada enjeksiyon sonrası üçüncü aya göre anlamlı olarak düşüktü. Enjeksiyon sonrası birinci hafta ve birinci ay etkisi arasında anlamlı fark saptanmadı. Hastalarda ciddi bir yan etki gözlenmedi.

Sonuç: Sonuç olarak, bu çalışmada IPH olan hastalarda. siyalore tedavisinde tükrük bezlerine BoNT-A enjeksiyonunun kolay, güvenli, tolere edilebilir ve etkili olduğu gösterilmiştir. Bununla birlikte, daha uzun süreli takip edilmiş ve daha büyük sayıda hasta içeren ileriye yönelik klinik çalışmalar sonuçlarımızı onaylamak ve uzatmak için gereklidir.

Anahtar Sözcükler: Botulinum toxin A; idiyopatik Parkinson hastalı̆̆l; siyalore. 